\title{
Innovative Ways on Ideological and Political Education Work of College Students under the New Situation
}

\author{
Jian Ding \\ College of Finance and Trade, Bohai University, Jinzhou, 121013, China \\ 7852196@qq.com
}

\begin{abstract}
Keywords: new situation; colleges and universities; ideological and political education; innovative ways; theoretical basis
\end{abstract}

\begin{abstract}
With the development of social economy, profound changes have taken place in the education environment. The university students' ideological and political education work has brought new opportunities and challenges. This paper summarized the theoretical basis of ideological and political work and analysis of university students' ideological and political education work is facing the new situation, to explore the new situation of ideological and political education work rule and method, is put forward under the new situation, the innovation of the colleges and universities student thought political education work. Specific include: improve ideological and political education by new media platform construction timeliness, mechanism of colleges and universities students' ideological and political education, and deepen the ideal faith education and civic education, give prominence to the ideological and political education at the concept of service for the society economy mobilization efforts together to construct a system of ideological and political education.
\end{abstract}

\section{Introduction}

Ideological work is a certain class or group to help people to establish the idea of is consistent with the social development request, the change of deviation from the idea of social development request, the purpose is to make people thought more accord with the objective reality, in order to better change the objective world. Political work is a certain class, political parties, and the group to achieve its program and basic task of the activity, such as class struggle, political power construction, the party's ideological and organizational construction, etc. Ideological and political education refers to a society or social groups with certain ideas, political views and ethics for members of the purposeful, planned and organized influence. It makes them form the accord with certain social, need a certain class ideology and moral character of social practice.

Colleges and universities students' ideological and political education work is an important part of ideological and political education work of the communist party of China. With scientific theory, viewpoint and method of education and guide the student world outlook and outlook on life, set up correct and lofty ideal faith, put their own value associated with the motherland and the people's interests, study hard, aspire to success, and serve the motherland. Through propaganda and education theory, make students form the national consciousness, political consciousness, national consciousness, legal consciousness, responsibility consciousness, equal consciousness, moral awareness and participation, shoulder the historical responsibility and sacred mission, enhance the party's affinity and cohesion, to realize the great rejuvenation of the Chinese nation, build a harmonious socialist society. The ultimate goal is to develop "moral, intellectual, physical, art" the comprehensive development of the socialist cause builders and successors.

Colleges and universities is the cradle of talent of education high quality, ideological and political education is to cultivate students' healthy personality, good personality, good character, enterprising spirit and innovation consciousness. With the historical progress and development of the era, ideological and political education work environment is undergoing profound changes, the ideological and political education work also put forward higher request, diverse ideas, new situations and new problems in the field of ideology, increase the complexity and difficulty of the 
ideological and political education work. Analysis, therefore, under the new situation, university students' ideological and political education work to appear new situation and new problems, and targeted to improve the ideological and political education content system, explore the regularity of ideological and political education work under the new situation and method, to realize the goal of China's higher education to cultivate has important theoretical and realistic significance.

\section{Theoretical Basis of Ideological and Political Work}

Basic theory refers to a subject category, judge and inference. Marxism and MAO zedong thought, Deng xiaoping theory and "three represents" important thought, the concept of scientific development, and the "China dream" thought is the theoretical basis of ideological and political education work.

(1) Marxism. Marxist historical materialism theory and method of ideological and political education was regarded as a kind of special social phenomenon, change, and development based on the social and historical conditions of reality. Marxist theory using the method of "empirical science", the ideological and political education as one of the aspects of social life, the specific process and mechanism analysis of its activities [1]. The ideological and political education of Marxism is a kind of consciousness to carry out the work, the ideological and political education of Marxism own class attributes do not need to outsiders.

(2) MAO zedong thought. MAO zedong the comparison of ideological and political work for the human soul, and think that "there is no correct political point of view, means no soul". Wide-ranging, MAO zedong's ideological and political education theory system embodied in political education, ideological education, moral education and discipline education for the two aspects, such as [2]. MAO zedong's theory of ideological and political education is in the concrete practice of Chinese revolution and socialist construction, combining the theory of Marxist ideological and political education, as a revolutionary in different periods and different stages to provide ideas for state construction

(3) Deng xiaoping theory. Deng xiaoping's theory of ideological and political education, is an important part of Deng xiaoping theory, is the fundamental assurance for the development of the cause of socialism with Chinese characteristics. Deng xiaoping pointed out that the ideological and political work should have a correct theory as the instruction, and to adhere to the theory with practice, according to the actual situation decision guidelines and principles [3]. Specific ideological and political work, adhere to the principle of serving the socialist economic construction, insist on combining solving ideological problems with solving practical problems of the principle, adhere to the principle of combining education and management.

(4) The "three represents" important thought. The communist party of China always represents the development of China's advanced productive forces. It always represents the direction of Chinese advanced culture, always on behalf of the Chinese people's fundamental interests. Colleges and universities should adhere to the "three represents" the important thoughts as the instruction, the innovation of ideological and political education work, the study of the "three represents" important thought to the ideological and political education work, into the idea of ideological and political workers and action to implement to go in the improvement of college students' ideological and political quality [4].

(5) The scientific outlook on development. The scientific development concept the first gist is development, the core is people-oriented, the basic requirement is comprehensive, balanced and sustainable, overall consideration as its fundamental approach. The concept of scientific development is comprehensive in the new period to strengthen and improve the party's ideological and political education theory of the powerful weapon [5]. Closely linked to the ideological and political education with the scientific concept of development, the study practice scientific development concept is dependent on the ideological and political education, ideological and political education must be guided by the scientific concept of development. The people-oriented core is to do a good job of ideological and political education. And it's also the core of the scientific outlook on development. 
(6) "China dream". "China dream" connotation is rich, the system, to a certain level has the characteristics of the theory and practice of ideological and political education. "Chinese dream" reveals the ideological and political education's political attribute and the "China dream" underlines the pursuit of the ideological and political education value, "China dream" expand the vision of ideological and political education theory [6]. "Chinese dream" has enriched the basic content of ideological and political education, the dominant contents and develops the content of sex. Improve the scientific level of ideological and political education practice and the system of ideological and political education theory.

\section{New Situation of Ideological and Political Education Work of College Students}

The current ideological and political education work is faced with many complicated new situation, mainly manifested in the following aspects:

(1) The cultural diversity. Cultural diversity refers to the human society is more and more complicated. The more information circulation to developed, the update transformation of culture is increasingly accelerated, all kinds of cultural development are faced with different opportunities and challenges, new culture will also emerge in endlessly. These cultural services in the development of the society, has created the diversity of culture, is the complicated social background of multi-culture. Multicultural to the impact of ideological and political education is characterized by: confusion and hesitation, aloof and indifferent, the crisis of belief and split, blind and impetuous, instability, no center and diversification, etc. [7].

(2) New media. New media is the use of digital technology and network technology, through the Internet, broadband local area network (LAN), wireless communication network and satellite channels, as well as computers, mobile phones and digital television terminal, to provide customers with the flow of information and entertainment services. New media makes the social environment and cultural environment of ideological and political education is more complex, to college students' life, study, psychology and values have brought a significant impact. New media technology provides a new form for ideological and political education for information collection, information content, information dissemination channels of great change.

(3) Economic globalization. Economic globalization refers to the world economic activities beyond borders, through foreign trade, capital flows, technology transfer, providing services, interdependence and mutual connection and the process of formation of global range of organic economy as a whole. Economic globalization to further explore the potential for ideological and political education provides a good foundation; Economic globalization for the ideological and political education provides an open social environment. The expansion of the western ideology differentiation and deconstruction of the ideological and political education guidance, the appearance of global problems increase the difficulty of the ideological and political education.

(4) Knowledge economy. Knowledge economy is dominant in the production of knowledge, knowledge industry as leading industry economic form. The development of knowledge economy, a more profound influence on college students, the ideological and political education work must keep pace with the development of knowledge economy era. The ideological and political education must build up his consciousness of the internationalization of the knowledge economy, knowledge economy demands the ideological and political education, which is based on science and technology, knowledge economy demands the ideological and political education to make students become the subject of the real demands of the knowledge economy of ideological and political education into the life world of students.

(5) Social transformation. The specific content of social transformation is forming structure transformation, mechanism switching, interests adjusting and concept transformation. In the period of social transformation, people's behavior mode, life style and value system will be significant changes in [8]. Theory of ideological and political education is faced with and the value of the dual dilemma. Theoretical difficulties mainly for later modernism trend and consumerism trend as a representative of the impact of the ideological trend of contemporary western society, the difficulty 
of college students' value orientation of value and social participation between in the "cold" and "radical".

(6) Popularization of higher education. Higher education from elite education to popular education change, education system, education environment, teaching mode, ideology and education object changes, also brings difference between colleges and universities, college students individual differences between increase, regional difference, has brought about great challenge to ideological and political education [9]. Main show is: scale brings to the ideological and political education team and management pressure, popular pressure for students increased the difficulty of the ideological and political education in colleges and universities, student individual contributed to the difference between the complexity of ideological and political education.

\section{Innovative Ways on Ideological and Political Education Work of College Students under the New Situation}

Colleges and universities students' ideological and political education work is facing the new situation, combining with the results of other literature $[10,12]$, this paper puts forward the college students' ideological and political education work innovation approach is as follows:

(1) Construct to improve the effectiveness of ideological and political education through new media platform. With the help of the new media of college ideological and political theory class, through new media technology of ideological and political education, improve teaching efficiency and make the education into the student life. Through various communication group of the construction of the new media technology, make students become the main body of education; Take advantage of new media technology solid, ideological and political education position through micro blog and cause students to focus on new media technologies such as network BBS public opinion hotspot, analyzes with the theory of ideological and political education, to guide college students health concept to the positive direction; Set up the ideological and political education workers of new media, and training related to the ideological and political education courses, take advantage of new media to improve the effect of ideological and political education, to promote the development of ideological and political education workers to "expert", the new media technology applied in the ideological and political education in routine work.

(2) Perfect the work mechanism of university students' ideological and political education. Mechanism of ideological and political education is the ideological and political education in the process of operation, the mechanism of constituent elements for some form of causal relationship and operation way. From the perspective of a long-term education practice, college students' ideological and political education work mechanism, mainly including leadership and management mechanism, education mechanism, guarantee mechanism, evaluation mechanism, incentive mechanism and supervision mechanism. A mechanism of these mechanisms links appear problem, will affect the whole work. The ideological and political education factors are interrelated, interaction of organic whole. Therefore, only to establish a harmonious and efficient operation mechanism, can make the ideological and political education to achieve the ideal effect, achieve the goal of ideological and political education innovation. Specific include: the perfection of the mechanism of education main body, improve the mechanism of the education goal, the perfection of the mechanism of education environment, building a harmonious teaching mechanism, and build a new interactive mechanism.

(3) Deepen ideal faith education and civil norms. The ideal and faith of the Chinese nation is the collection of the wisdom and the strength of the whole nation, for the cause of socialism and the great rejuvenation of the Chinese nation and make unremitting struggle, this also should be the pursuit of the ideal faith to the contemporary college students. Ideological and political education depends on the ideal faith education for university students, and to change the non-computer majors preaching and tree typical type of preaching, should be based on the cultivation of the students of faith and the pursuit of the ideal. Citizen moral level but also the key factors that affect China's social progress, moral education of college students on campus to accept than after entering society to accept the basic moral education more solid, promote the university students to form good moral 
sentiment and moral cultivation, in training students' ideal and faith of life and at the same time, make the students to build a strong social morality, professional ethics and family virtue, clear what college students should do and how to be a man.

(4) Highlight the ideological and political education for the concept of social and economic services. Ideological and political education in the era of knowledge economy requires college students based on national conditions, on the basis of establishing the global consciousness and the history of the world, break through the original do not conform to the era of the development of the old ideas and enhance the effectiveness of the ideological and political education of university students. The economic function of the ideological and political education in the era of knowledge economy highlights, factors such as information, knowledge and education are playing an increasingly important role in the economic development, and gradually become a key factor in the development of knowledge economy. Ideological and political education to better service for the economy in the era of knowledge economy, focuses on the function and cultivate students have higher political ideological and political quality at the same time, combine quality education to cultivate, formed to adapt to the era of knowledge economy's values, ethics and innovation consciousness and subject consciousness, etc.

(5) Mobilize all forces to construct a system of ideological and political education. Ideological and political education is a huge system project, should make full use of family, school and social power and so on various aspects of resources. School education, family education and social education and promote each other, complement each other. Family education is the basis and starting point of the ideological and political education, school education is the main position of ideological and political education, social education is extension and supplements of the family education and school education, which in turn affect and restrict the family education and school education. Therefore, only the family education, school education and social education combine each other, can make the ideological and political education to form a system, internal system and link closely combined, promote each other, can be achieved finally obtain the best effect of ideological and political education.

\section{Conclusion}

To strengthen and improve ideological and political education, and improve the ideological and political quality, training to become builders and successors to the cause of socialism with Chinese characteristics, the science and education to fully implement and the strategy of reinvigorating China through human resource development, in the fierce international competition to ensure that China is always in an impregnable position, ensure the comprehensive construction well-off society and accelerating socialist modernization goals, to ensure that the cause of socialism with Chinese characteristics to thrive, happiness, has great and far-reaching strategic significance. The new situation of university students' ideological and political education work puts forward a new challenge, this paper puts forward the innovative way of provides a method to meet the new challenge and strategy, to strengthen students' ideological and political education under the new situation, the comprehensive implementation of higher education plays an important role on training goal.

\section{References}

[1] D. S. Wu, "Principles of Marxism Theories on the Nature of Ideological and Political Education," Teaching and Research, vol. 62, no. 2, pp. 70-75, 2014.

[2] Y. Y. Wang, X. P. Han, "On Mao Zedong's theory of Ideological and Political Education," Journal of Northeast Agricultural University (Social Science Edition), vol. 11, no. 2, pp. 54-56, 2013.

[3] Y. Zheng, " "Briefly on Deng Xiaoping's Theory of Ideological and Political Education," Social Sciences Journal of Universities in Shanxi, vol. 22, no. 5, pp. 8-11, 2010. 
[4] A. F. Li, "The thought of "Three Representatives" and the work of Ideological and political education in Colleges and universities in the new era," Journal of Mudanjiang Teachers College, vol. 31, no. 4, pp. 78-80, 2005.

[5] Z. G. Du, H. Wang, "Analysis of Scientific Outlook on Development and the ideological and Political Education," Legal System and Society, vol. 6, no. 13, pp. 225-226, 2011.

[6] Y. N. Ma, Y. G. Ji, "Preliminary exploration on ideological and political education function of "Chinese dream"," Ideological and Political Education Research, vol. 29, no. 5, pp. 10-13, 2013.

[7] H. F. Zhang, Y. Tang, "The impact of multi culture on ideological and political education and tts countermeasures," Data of Culture and Education, vol. 51, no. 2, pp. 203-204, 2008.

[8] D. B. Cao, "Two difficulties and solutions of Ideological and political education in Colleges and universities during the period of social transformation," Higher Education Exploration, vol. 27, no. 5, pp. 139-142, 2011.

[9] J. Liu, "New characteristics of college students' thought in the background of higher education popularization," Journal of Changchun Education Institute, vol. 30, no. 4, pp. 43-44, 2014.

[10] Y. Y. Jia, "Challenges and countermeasures of ideological and political education in colleges and universities under the new situation," Education and Vocation, vol. 99, no. 11, pp. 39-41, 2015.

[11] W. W. Zhu, "On the innovation principle of ideological and political education in the new situation," Journal of Heilongjiang Institute of Socialism, vol. 21, no. 1, pp. 53-56, 2015.

[12] B. Hu, "On how to expand the effective way of Ideological and political education of College Students under the new situation," Journal of Lanzhou Institute of Education, vol. 32, no. 4, pp. 59-61, 2016. 